\title{
Protein and lipid metabolism adjustments in silver catfish (Rhamdia quelen) during different periods of fasting and refeeding
}

\author{
A. Marqueze ${ }^{a *}$, C. F. Garbino ${ }^{a}$, M. Trapp ${ }^{b}$, L. C. Kucharski ${ }^{b}$, M. Fagundes , D. Ferreira $^{c}$, \\ G. Koakoskid and J. G. S. Rosa ${ }^{d}$
}

a'Mestrado de Avaliação em Impactos Ambientais, Centro Universitário Lassalle - Unilasalle, Av. Victor Barreto, 2288, CEP 92010-000, Canoas, RS, Brazil

${ }^{b}$ Departamento de Fisiologia, Universidade Federal do Rio Grande do Sul - UFRGS, Rua Sarmento Leite, 500, CEP 90050-170, Porto Alegre, RS, Brazil

${ }^{\mathrm{C} C u r s o ~ d e ~ M e d i c i n a ~ V e t e r i n a ́ r i a, ~ U n i v e r s i d a d e ~ d e ~ P a s s o ~ F u n d o ~-~ U P F, ~ C a m p u s ~ I, ~}$ São José, CP 611, CEP 99001-970, Passo Fundo, RS, Brazil

dPrograma de Pós-graduação em Farmacologia, Universidade Federal de Santa Maria - UFSM, Avenida Roraima, 1000, Cidade Universitária, Camobi, CEP 97105-900, Santa Maria, RS, Brazil

*e-mail: alessandra@unilasalle.edu.br

Received: September 15, 2016 - Accepted: February 21, 2017 - Distributed: October 31, 2018

\begin{abstract}
The fish may experience periods of food deprivation or starvation which produce metabolic changes. In this study, adult Rhamdia quelen males were subjected to fasting periods of 1,7,14, and 21 days and of refeeding 2, 4, 6, and 12 days. The results demonstrated that liver protein was depleted after 1 day of fasting, but recovered after 6 days of refeeding. After 14 days of fasting, mobilization in the lipids of the muscular tissue took place, and these reserves began to re-establish themselves after 4 days of refeeding. Plasmatic triglycerides increased after 1 day of fasting, and decreased following 2 days of refeeding. The glycerol in the plasma oscillated constantly during the different periods of fasting and refeeding. Changes in the metabolism of both protein and lipids during these periods can be considered as survival strategies used by $R$. quelen. The difference in the metabolic profile of the tissues, the influence of the period of fasting, and the type of reserves mobilized were all in evidence.
\end{abstract}

Keywords: fasting, lipids, protein, refeeding, silver catfish.

\section{Ajustes no metabolismo de proteínas e lipídios no jundiá (Rhamdia quelen) durante diferentes períodos de jejum e realimentação}

\section{Resumo}

Os peixes podem sofrer períodos de privação de alimentos ou de fome, que produzem mudanças metabólicas. Neste estudo, jundiás machos adultos foram submetidos a jejum períodos de 1, 7, 14 e 21 dias e realimentação 2, 4, 6, e 12 dias. Os resultados demonstraram que a proteína do fígado foi esgotada depois de um dia de jejum, mas restabeleceu após 6 dias de realimentação. Após 14 dias de jejum, ocorreu a mobilização dos lípidos no tecido muscular sendo que estas reservas começaram a re-estabelecer-se após 4 dias de realimentação. Os triglicérides plasmáticos aumentam após um dia de jejum, e diminuiram após 2 dias de realimentação. $\mathrm{O}$ glicerol no plasma oscilou constantemente durante os diferentes períodos de jejum e realimentação. As alterações no metabolismo de proteína e lipídios durante estes períodos podem ser consideradas uma estratégias de sobrevivência utilizada pelo Rhamdia quelen. Sendo que a diferença no perfil metabólico tecidual bem como a influência do período de jejum e o tipo de reserva a ser mobilizada foram observadas neste estudo.

Palavras-chave: jejum, lipídios, proteína, realimentação, jundiá.

\section{Introduction}

In subtropical climate zones of the world, fish species used for aquaculture must grow rapidly during the summer and withstand low temperatures in the winter season. In this context, a promising fish species for aquaculture is the South American catfish, Rhamdia quelen
(Teleostei:Pimelodidae), that exhibits high prolificacy and fast weight gain, particularly in the warmer months of the year (Gomes et al., 2000). Due to these characteristics, $R$. quelen fish have been intensively cultured, and have even been used as a model to improve the management 
of several other species of fish in the Pimelodidae family (Barcellos et al., 2001).

$R$. quelen, as with other fish species, may experience periods of food deprivation or starvation - both in natura (due to limited food availability in winter and the reduction in food intake associated with life-cycle phenomena, e.g., spawning migration) and also in aquaculture (due to pre-harvest fasting, as well as shipping management and feeding regimes, which restrict availability of food) (Mackenzie et al., 1998; Souza et al., 2003; Camargo and Urbinati, 2008). Natural or artificial fasting periods produce a number of hormonal and biochemical changes, including reduction in muscle glycogen and mobilization of fat and protein, which may impair fish meat quality (Sigholt et al., 1997; Thomas et al., 1999).

Fish use food primarily to meet energy requirements for maintaining vital processes and restoring tissue catabolism (Hepher, 1988). Fasting induces a complex series of changes that regulate biological functions, and its ultimate consequences are highly dependent upon the fish species and age, as well as on experimental conditions, e.g., water temperature, photoperiod, and pre-fasting diet (Love, 1980; Weatherley and Gill, 1987; Blasco et al., 1991). Hematological studies on R.quelen are present in the literature (Fukushima et al., 2012) and Nilo Tilápia (Jeronimo et al., 2011), also on the feeding by jundiá (Brandão-Gonçalves and Sebastien, 2013) however studies that can elucidate the influence of fasting on metabolism are rare. Therefore, studies on metabolism in relation to different periods of fasting is of paramount importance since it will show which metabolic adjustments will be necessary to maintain the homeostasis of the species, showing which reserves will be mobilized or not for their survival. Barcellos et al. (2010) have described alterations in the carbohydrate metabolism of $R$. quelen during different periods of fasting and refeeding. In this study, endocrinal alterations were observed as being responsible for an increase in the levels of cortisol, a hormone which undergoes change in situations of stress and causes a number of physiological modifications in the metabolism of carbohydrates, proteins and lipids.

As such, this study aims to evaluate the use of protein and lipid reserves in $R$. quelen fish as energy sources, following different periods of food deprivation and refeeding.

\section{Material and Methods}

\subsection{The fish}

Six-month-old $R$. quelen males weighing $375.9 \pm 43.9 \mathrm{~g}$ were kept under natural photoperiod conditions in two 6,200 -L plastic tanks with water change $\left(10 \%\right.$ day $\left.^{-1}\right)$ prior to distribution to experimental tanks. They were fed twice a day (at 10 a.m. and 4 p.m.) with $42 \%$ extruded crude protein $\left(3400 \mathrm{kcal} \mathrm{kg}^{-1} \mathrm{DE}\right)$, corresponding to $5 \%$ of their body weight. Water temperature and dissolved oxygen concentrations (YSI 550A oxygen meter; Yellow Spring Instruments, Yellow Springs, OH, USA) were monitored. The $\mathrm{pH}$ values (Bernauer $\mathrm{pH}$ meter, Indaial, SC, Brazil), total ammonia-N (colorimetric test), total alkalinity, and hardness were also measured.

\subsection{Experimental design}

The fish were divided into 5 experimental groups. Group I was fed on a normal diet (control group). The fish in the other groups were subjected to a period of fasting for 1 day (group II), 7 days (group III), 14 days (group IV), and 21 days (group V). All the fish were refed at the end of each fasting period. Each group had four 3000-L concrete tanks with 20 fish in each one (stocking density of approximately $2.4 \mathrm{~g} \mathrm{~L}^{-1}$ ). The fish were kept in the tanks over a 5-day period, as described in previous reports using the same species (Barcellos et al., 2006, 2010). During the experimental period, the water quality parameters determined were as follows: temperature, $24.6 \pm 0.08{ }^{\circ} \mathrm{C}$; dissolved oxygen, $6.2 \pm 0.01 \mathrm{mg} \mathrm{L}^{-1 ;} \mathrm{pH}, 7.3 \pm 0.01$; total hardness and alkalinity, 60 and $65 \mathrm{mg} \mathrm{L}^{-1} \mathrm{CaCO}_{3}$, respectively. $\mathrm{NH}_{4}$ and $\mathrm{NO}_{2}$ content did not exceed $0.5 \mathrm{mg} \mathrm{L}^{-1}$.

Since a dark environment is preferred by $R$. quelen, all the tanks were covered with a layer of thin black plastic to prevent stress caused during management of adjacent tanks, but light was not totally excluded. This situation it is similar replicates the natural habitat of this species, i.e., river bottoms with high turbidity (Gomes et al., 2000; Barcellos et al., 2009).

During the refeeding period, the fish were fed to near to satiation (verified by observation of their feeding behavior) via a small hole in each black plastic cover. Faeces and food residues were not siphoned off, in order to prevent stress caused during management. The experiment was conducted during the summer months, with an average temperature of $24.6 \pm 0.08{ }^{\circ} \mathrm{C}$.

\subsection{Sampling}

Blood samples were obtained from the control group and from groups II, III, IV, and IV after 1, 7, 14, and 21 days of fasting, respectively 12 fish ( 3 from each of the 4 anks) were randomly captured using a pen net. During the refeeding period, a further 12 fish ( 3 per tank) from each group were sampled at the time of refeeding, and thereafter on days $2,4,6$, and 12 . At the end of each fasting/refeeding period, the fish were captured and anaesthetized with MS222 (300 mg L-1, Argent Redmond, WA, USA). Blood samples were then drawn from the caudal vessels using heparinized syringes. Following this, the fish were killed by means of spinal section, and liver and muscle tissue was removed, weighed, placed on ice, frozen in liquid nitrogen and stored at $-20^{\circ} \mathrm{C}$ for later analysis. The blood samples mentioned above were then centrifuged $(3000 \times \mathrm{g}, 10 \mathrm{~min})$, and the plasma was stored at $-25^{\circ} \mathrm{C}$ for later analysis.

\subsection{Blood and tissue analysis}

Total lipids were extracted using a 2:1 ratio of chloroform to methanol solution, and were quantified by means of the sulfo-phospho-vanillin method (Folch et al., 1957). Purpose-made kits were used to measure plasma triglyceride concentrations (Triglycerides Liquiform; Labtest, Lagoa Santa, MG, Brazil) and plasma glycerol 
levels (R-Biopharm, Darmstadt, Germany). Protein levels in the liver and muscle tissues were determined according to the Bradford (1976) method.

\subsection{Statistical analysis}

The mean \pm SEM value of each group was calculated using the GraphPad InStat 3 statistical package (GraphPad Software, San Diego, CA, USA) and compared by one-way analysis of variance (ANOVA), followed by the Tukey test. Statistical significance was accepted as being $p<0.05$. The Hartley test was carried out to verify the homogeneity of variance, and normality was verified using the Kolmogorov-Smirnov test. Log-transformation was performed where necessary, and non-transformed data are presented in the tables below.

All the procedures involving animals were conducted in compliance with the guidelines approved by the Committee on Research Ethics and Animal Welfare of the Universidade de Passo Fundo (UPF). The authors declare that there is no conflict of interest in this regard.

\section{Results}

In the liver (Table 1) of the catfish, protein reserves were reduced $(p<0.05)$ in groups II and III after 1 and 7 days of fasting respectively, group IV (14 days), and group V (21 days).
In groups III and IV, these values were similar to those of the control group. The change in protein reserves in the liver in all groups persisted until the sixth day of re-feeding, and then began to increase $(\mathrm{p}<0.05)$ in group II and group III. In the other groups (IV and V), where the fasting period was longer, protein reserves were not restored during the 12-day re-feeding period.

In contrast, muscle proteins remained unchanged during the fasting period (Table 2). However, a decrease $(\mathrm{p}<0.05)$ in muscle protein was observed in group III during different re-feeding periods.

The different fasting periods did not significantly alter reserves of liver lipids (Table 3 ). However, during the re-feeding of group III (7 days of fasting) and group IV (4 days of fasting) there was an increase in lipid reserves in this tissue from the $4^{\text {th }}$ day of re-feeding in group III, and from the $12^{\text {th }}$ day of re-feeding in group IV.

In the muscle tissue (Table 4), a decrease was observed $(p<0.005)$ in the lipid reserves from the $14^{\text {th }}$ day (group IV) of fasting. After 4 days of re-feeding, these reserves returned to values similar to those of the control group (group I).

Plasma triglyceride levels (Table 5) increased significantly in group II (after 1 day of fasting), but fell again after 2 days of re-feeding. In group III (7 days of fasting), triglyceride levels increased after 4 days of re-feeding, a

Table 1. Liver protein content ( $\mathrm{mg} \mathrm{g}^{-1}$ tissue) after different fasting periods and during re-feeding.

\begin{tabular}{|c|c|c|c|c|c|c|}
\hline & \multicolumn{5}{|c|}{ Experimental groups } \\
\hline & & I (control) & II (1d) & III(7d) & IV (14d) & V (21d) \\
\hline \multirow{5}{*}{ 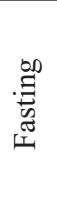 } & $0 \mathrm{~d}$ & $0.40 \pm 0.06 \mathrm{~A}$ & & & & \\
\hline & $1 d$ & & $0.03 \pm 0.01 \mathrm{cC}$ & & & \\
\hline & $7 d$ & & & $0.26 \pm 0.01 \mathrm{cB}$ & & \\
\hline & $14 d$ & & & & $0.28 \pm 0.01 \mathrm{AB}$ & \\
\hline & $21 d$ & & & & & $0.31 \pm 0.03 \mathrm{AB}$ \\
\hline \multirow{4}{*}{ 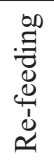 } & $2 d$ & $0.43 \pm 0.01$ & $0.13 \pm 0.03 c$ & $0.27 \pm 0.01 \mathrm{c}$ & $0.33 \pm 0.04$ & $0.25 \pm 0.02$ \\
\hline & $4 d$ & $0.46 \pm 0.06$ & $0.16 \pm 0.01 b c$ & $0.27 \pm 0.01 \mathrm{c}$ & $0.28 \pm 0.04$ & $0.28 \pm 0.02$ \\
\hline & $6 \mathrm{~d}$ & $0.47 \pm 0.05$ & $0.19 \pm 0.08 b$ & $0.33 \pm 0.01 b$ & $0.29 \pm 0.01$ & $0.22 \pm 0.08$ \\
\hline & $12 d$ & $0.43 \pm 0.04$ & $0.55 \pm 0.09 \mathrm{a}$ & $0.78 \pm 0.02 \mathrm{a}$ & $0.31 \pm 0.09$ & $0.23 \pm 0.07$ \\
\hline
\end{tabular}

Small letters in the columns indicates statistical differences between the different sample days within the same group and the capital letters indicates statistical differences between the different days of fasting $(P<0.05 ; n=12)$.

Table 2. Muscle protein content ( $\mathrm{mg} \mathrm{g}^{-1}$ tissue) after different fasting periods and during re-feeding.

\begin{tabular}{|c|c|c|c|c|c|c|}
\hline & & \multicolumn{5}{|c|}{ Experimental groups } \\
\hline & & I (control) & II (1d) & III(7d) & IV (14d) & $V(21 d)$ \\
\hline \multirow{5}{*}{ 䒫 } & $0 \mathrm{~d}$ & $0.652 \pm 0.08$ & & & & \\
\hline & $1 d$ & & $0.605 \pm 0.042 b$ & & & \\
\hline & $7 d$ & & & $0.600 \pm 0.05 a$ & & \\
\hline & $14 d$ & & & & $0.497 \pm 0.073 b$ & \\
\hline & $21 d$ & & & & & $0.591 \pm 0.02 \mathrm{a}$ \\
\hline \multirow{4}{*}{ 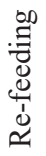 } & $2 d$ & $0.657 \pm 0.08$ & $0.495 \pm 0.011 b$ & $0.112 \pm 0.009 b$ & $0.494 \pm 0.02 \mathrm{ab}$ & $0.492 \pm 0.04 a$ \\
\hline & $4 d$ & $0.69 \pm 0.08$ & $0.622 \pm 0.083 b$ & $0.171 \pm 0.04 \mathrm{~b}$ & $0.425 \pm 0.015 b$ & $0.485 \pm 0.02 \mathrm{a}$ \\
\hline & $6 \mathrm{~d}$ & $0.63 \pm 0.09$ & $0.68 \pm 0.05 b$ & $0.134 \pm 0.05 b$ & $0.433 \pm 0.01 b$ & $0.520 \pm 0.02 \mathrm{a}$ \\
\hline & $12 \mathrm{~d}$ & $0.67 \pm 0.08$ & $0.565 \pm 0.05 b$ & $0.211 \pm 0.09 b$ & $0.468 \pm 0.08 b$ & $0.512 \pm 0.02 \mathrm{a}$ \\
\hline
\end{tabular}

Small letters in the columns indicates statistical differences between the different sample days within the same group $(P<0.05$; $n=12)$. 
Table 3. Total liver lipid content ( $\mathrm{mg} \mathrm{g}^{-1}$ tissue) after different fasting periods and during re-feeding.

\begin{tabular}{|c|c|c|c|c|c|c|}
\hline & & \multicolumn{5}{|c|}{ Experimental groups } \\
\hline & & I (control) & II (1d) & III(7d) & IV (14d) & V (21d) \\
\hline \multirow{5}{*}{ 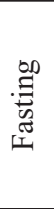 } & $0 \mathrm{~d}$ & $20.1 \pm 5.5$ & & & & \\
\hline & $1 d$ & & $26.6 \pm 11.5$ & & & \\
\hline & $7 d$ & & & $16.2 \pm 0.6 b$ & & \\
\hline & $14 \mathrm{~d}$ & & & & $12.7 \pm 3.3 b$ & \\
\hline & $21 d$ & & & & & $30.1 \pm 7.3$ \\
\hline \multirow{4}{*}{ 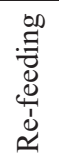 } & $2 d$ & $19.9 \pm 5.9$ & $32.8 \pm 14.2$ & $14.1 \pm 1.3 b$ & $10.1 \pm 3.8 b$ & $30.7 \pm 8.3$ \\
\hline & $4 d$ & $19.8 \pm 5.6$ & $19.2 \pm 5.1$ & $24.5 \pm 6.1 \mathrm{a}$ & $9.7 \pm 2.2 b$ & $25.7 \pm 5.3$ \\
\hline & $6 \mathrm{~d}$ & $18.9 \pm 4.9$ & $19.0 \pm 7.0$ & $20.2 \pm 4.3 \mathrm{a}$ & $9.3 \pm 5.5 b$ & $23.0 \pm 4.2$ \\
\hline & $12 \mathrm{~d}$ & $21.1 \pm 5.8$ & $18.5 \pm 6.8$ & $19.1 \pm 5.8 \mathrm{a}$ & $21.5 \pm 4.0 \mathrm{a}$ & $20.0 \pm 5.1$ \\
\hline
\end{tabular}

Small letters in the columns indicates statistical differences between the different sample days within the same group $(P<0.05$; $n=12)$.

Table 4. Total muscle lipid content ( $\mathrm{mg} \mathrm{g}^{-1}$ tissue) after different fasting periods and during re-feeding.

\begin{tabular}{|c|c|c|c|c|c|c|}
\hline & & \multicolumn{5}{|c|}{ Experimental groups } \\
\hline & & I (control) & II (1d) & III(7d) & IV (14d) & $V(21 d)$ \\
\hline \multirow{5}{*}{ 䒫 } & $0 \mathrm{~d}$ & $6.2 \pm 1.4 \mathrm{~A}$ & & & & \\
\hline & $1 d$ & & $8.8 \pm 2.4 \mathrm{~A}$ & & & \\
\hline & $7 \mathrm{~d}$ & & & $6.5 \pm 2.6 \mathrm{~A}$ & & \\
\hline & $14 d$ & & & & $2.1 \pm 0.2 \mathrm{Bb}$ & \\
\hline & $21 \mathrm{~d}$ & & & & & $1.1 \pm 0.08 \mathrm{Bc}$ \\
\hline \multirow{4}{*}{ 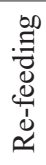 } & $2 d$ & $6.1 \pm 1.5$ & $15.2 \pm 7.3$ & $12.4 \pm 4.1$ & $3.2 \pm 0.9 b$ & $1.2 \pm 0.1 \mathrm{c}$ \\
\hline & $4 d$ & $5.9 \pm 1.1$ & $11.7 \pm 6.8$ & $11.8 \pm 1.9$ & $8.2 \pm 2.1 \mathrm{a}$ & $3.3 \pm 1.1 \mathrm{~b}$ \\
\hline & $6 \mathrm{~d}$ & $6.9 \pm 2.1$ & $10.6 \pm 6.0$ & $9.5 \pm 4.1$ & $10.1 \pm 1.9 \mathrm{a}$ & $7.0 \pm 1.1 \mathrm{a}$ \\
\hline & $12 \mathrm{~d}$ & $6.6 \pm 1.8$ & $10.0 \pm 5.7$ & $7.4 \pm 3.3$ & $7.7 \pm 1.7 \mathrm{a}$ & $7.1 \pm 2.1 \mathrm{a}$ \\
\hline
\end{tabular}

Small letters in the columns indicates statistical differences between the different sample days within the same group and the capital letters indicates statistical differences between the different days of fasting $(P<0.05 ; n=12)$.

Table 5. Plasmatic triglycerides $\left(\mathrm{mg} \mathrm{mL}^{-1}\right)$ after different fasting periods and during re-feeding.

\begin{tabular}{|c|c|c|c|c|c|c|}
\hline & & \multicolumn{5}{|c|}{ Experimental groups } \\
\hline & & I (control) & II (1d) & III(7d) & IV (14d) & $V(21 d)$ \\
\hline \multirow{5}{*}{ 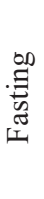 } & $0 \mathrm{~d}$ & $158.5 \pm 20.2 \mathrm{~B}$ & & & & \\
\hline & $1 d$ & & $748.9 \pm 92.5 \mathrm{aA}$ & & & \\
\hline & $7 d$ & & & $210.1 \pm 32.5 b B$ & & \\
\hline & $14 d$ & & & & $117.7 \pm 7.1 \mathrm{bB}$ & \\
\hline & $21 d$ & & & & & $212.1 \pm 53.8 \mathrm{~B}$ \\
\hline \multirow{4}{*}{ 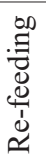 } & $2 d$ & $145.7 \pm 21.1$ & $388.4 \pm 67.8 b$ & $274.8 \pm 36.6 b$ & $133.1 \pm 9.8 b$ & $338.7 \pm 101.2$ \\
\hline & $4 d$ & $158.2 \pm 22.1$ & $222.5 \pm 26.9 b$ & $322.4 \pm 533 \mathrm{ab}$ & $222.1 \pm 36.5 \mathrm{a}$ & $314.1 \pm 38.9$ \\
\hline & $6 \mathrm{~d}$ & $160.0 \pm 58.7$ & $318.8 \pm 92.1 b$ & $325.5 \pm 56.6 \mathrm{ab}$ & $167.7 \pm 9.1 \mathrm{ab}$ & $375.4 \pm 89.9$ \\
\hline & $12 \mathrm{~d}$ & $155.5 \pm 21.4$ & $235.1 \pm 65.1 b$ & $500.1 \pm 65.8 \mathrm{a}$ & $247.1 \pm 21.1 \mathrm{a}$ & $531.1 \pm 77.1$ \\
\hline
\end{tabular}

Small letters in the columns indicates statistical differences between the different sample days within the same group and the capital letters indicates statistical differences between the different days of fasting $(P<0.05 ; n=12)$.

phenomenon which was similar to the effect observed in group IV (14 days of fasting).

During the different periods of fasting an oscillation in plasma glycerol was observed (Table 6). There was a significant increase after 1 day of fasting (group II), but when the fasting period was longer, as in group III (7 days) and group IV (14 days), the values of plasma metabolite decreased $(p<0.005)$ to values similar to those of the control group. However, when fasting lasted for 21 days (group V), plasma glycerol values began to increase again, just as in group II. During the refeeding periods, a different response in each group was observed (there was a decrease in values in groups II and III, and an increase in group IV).

\section{Discussion}

Studies evaluating the mobilization of reserves during fasting have reported that protein was the last nutrient to be used up (Black and Love, 1986; Bines, 1999; Hervant et al., 
Table 6. Plasma glycerol $\left(\mathrm{g} \mathrm{L}^{-1}\right)$ after different fasting periods and during re-feeding.

\begin{tabular}{|c|c|c|c|c|c|c|}
\hline & & \multicolumn{5}{|c|}{ Experimental groups } \\
\hline & & I (control) & II (1d) & III(7d) & IV (14d) & $V(21 d)$ \\
\hline \multirow{5}{*}{ 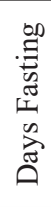 } & 0 & $0.010 \pm 0.002 \mathrm{~B}$ & & & & \\
\hline & 1 & & $0.100 \pm 0.014 \mathrm{aA}$ & & & \\
\hline & 7 & & & $0.024 \pm 0.007 \mathrm{bB}$ & & \\
\hline & 14 & & & & $0.010 \pm 0.002 \mathrm{bB}$ & \\
\hline & 21 & & & & & $0.148 \pm 0.060 \mathrm{~A}$ \\
\hline \multirow{4}{*}{ 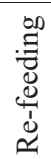 } & 2 & $0.008 \pm 0.003$ & $0.015 \pm 0.004 b$ & $0.028 \pm 0.002 b$ & $0.070 \pm 0.024 \mathrm{ab}$ & $0.084 \pm 0.010$ \\
\hline & 4 & $0.010 \pm 0.001$ & $0.034 \pm 0.011 b$ & $0.014 \pm 0.002 \mathrm{ab}$ & $0.090 \pm 0.022 \mathrm{ab}$ & $0.056 \pm 0.021$ \\
\hline & 6 & $0.009 \pm 0.003$ & $0.028 \pm 0.007 \mathrm{~b}$ & $0.043 \pm 0.003 a$ & $0.110 \pm 0.033 \mathrm{a}$ & $0.036 \pm 0.020$ \\
\hline & 12 & $0.007 \pm 0.001$ & $0.019 \pm 0.009 b$ & $0.029 \pm 0.002 \mathrm{ab}$ & $0.070 \pm 0.012 \mathrm{ab}$ & $0.058 \pm 0.030$ \\
\hline
\end{tabular}

Small letters in the columns indicates statistical differences between the different sample days within the same group and the capital letters indicates statistical differences between the different days of fasting $(P<0.05 ; n=12)$.

1999; Caloin, 2004). However, in the present study, we have demonstrated that protein mobilization is the primary energy source in food-deprived adult $R$. quelen. This is an unusual pattern, and represents a significant finding, since fish may experience limited food availability and a reduction in food intake, both in natura and in aquaculture, e.g., during pre-harvest fasting, shipping management, and feeding regimes that restrict food availability (Mackenzie et al., 1998; Souza et al., 2003; Camargo and Urbinati, 2008). Like all animals, fish need protein, fat, carbohydrates, vitamins, minerals, and other dietary elements to satisfy their physiological needs for growth and reproduction (Hertrampf and Piedad-Pascual, 2000).

A marked reduction in liver protein was observed during the different fasting periods, and mobilization of liver protein reserves began only 1 day after fasting. According to Rossi et al. (2015), the liver is the tissue which is most active metabolically in the mobilization of energy stocks to satisfy physiological needs. Kim et al. (2014) have also observed a decrease in plasma protein in the olive flounder during starvation. This initial reduction in protein reserves demonstrates the high susceptibility of this species to situations of food restriction. However, when this fasting period is longer (14 days and 21 days), mobilization appears to decrease.

No significant difference was found in muscle protein levels, suggesting that, in the case of catfish, these reserves are not mobilized during a 21-day fasting period.

Another factor to consider is the type of tissue in which the protein is stored and the length of fasting to which the fish are exposed. This demonstrated a different metabolic profile of muscle tissue in relation to fasting.

Other species of fish also use muscle protein as their primary fuel source, such as the European eel (Anguilla anguilla Linnaeus), goldfish (Carassius auratus Linnaeus), and plaice (Pleuronectes platessa Linnaeus), as reviewed by Czesny et al., (2003). However, the length of time between the beginning of the fasting period and protein mobilization for these species was generally of several days. Furthermore, this mobilization was shown to begin after 8 days of fasting in common carp (Cyprinus carpio Linnaeus) (Blasco et al., 1992), 21 days in sea bream (Sparus aurata Linnaeus)
(Power et al., 2000), and 50 days in salmon trout (Salmo trutta fario) (Navarro et al., 1992). Thus species is a key determining factor in the length of time required for protein mobilization following fasting. In addition, protein catabolism in rainbow trout (Oncorhynchus mykiss Walbaum) is active after 28 days of fasting, as indicated by high levels of transaminases (Kullgren et al., 2010).

Following the initial protein mobilization observed in the present study, protein liver stores were re-established within 6 days of refeeding, whilst with 12 days of refeeding nominal protein values are superior to control group values. This suggests a possible increase in protein reserves to provide for future fasting situations. For example, sea bream protein reserves were reestablished after 7 days of refeeding (Power et al., 2000). According to McCue (2010), successful strategies for maintaining homeostasis during periods of fasting are developed via mobilization of endogenous physiological energy sources, such as proteins, lipids and carbohydrates, which can respond to demand and ensure survival.

Despite the fact that numerous studies have highlighted the biological importance of lipids as a source of energy in fish (Stirling, 1976; Reinitz, 1983; Alliot et al., 1984), the liver lipid reserves of $R$. quelen were not significantly modified during the fasting period. This may be explained by the primary mobilization of liver protein at the beginning of fasting. However, following a longer period of fasting (14 days), the muscular reserves of lipids are mobilized, thus increasing levels of plasmatic triglycerides. According to Furné et al. (2012), the mobilization of hepatic reserves of lipids is related to species, the tissue of the reserves, and the strategies via which a particular species can mobilize other energy sources.

Triglycerides are formed by sterification of a glycerol molecule with 3 fatty acids (FA), and represent the main type of fat that constitutes lipid reserves (Van den Thillart and Van Raaij, 1995). The first step in their use as an energy source involves hydrolysis of triglycerides into FA and glycerol. The model for distribution and transport of lipids in fish consists of rapid and/or slow release in function of the chain length (Sheridan, 1988). Thus, the high triglyceride and glycerol levels found at the beginning 
of the fasting period demonstrate rapid energy release into the circulation in order to maintain homeostasis. Several studies have demonstrated that plasma free FA levels increase in fish subjected to fasting regimens (Lewis and Epple, 1984; Machado et al., 1988, 1989; Shimeno et al., 1990; Sheridan and Mommsen, 1991; Souza et al., 2000; Figueiredo-Garutti et al., 2002). The elevation in plasma glycerol levels observed in the present study suggest that $R$. quelen mobilized glycerol from lipid stores (mesenteric, muscle, belly flap, and liver), as has been observed in other fish species (Albalat et al., 2006; Farbridge et al., 1992; Navarro et al., 1992).

Fatty acid mobilization during a fasting period is essential for control of glucose levels. The increase in free FAs could competitively inhibit glucose mobilization by peripheral tissues and the release of glucose by the liver. In turn, higher fatty acid uptake by the liver stimulates lipid metabolism, glucose homeostasis, and lipid gluconeogenesis (Souza et al., 2000).

Based on the literature and our results, we can conclude that length of fasting period and species-related metabolic differences were determining factors for the type of reserves mobilized. Barcellos et al., (2010) observed that R. quelen mobilizes its glycogen reserves after 7 days of fasting. These data reinforce those reviewed by Love (1980); certain fish species mobilize proteins as their primary energy source (Butler, 1968; Narasimhan and Sundararaj, 1971); proteins and lipids are mobilized simultaneously (Larsson and Lewander, 1973), whereas other species maintain protein levels by mobilizing fat and/or glycogen (Inui \& Oshima, 1966; Kamra, 1966; Ince and So, 1984).

In conclusion, changes in the metabolism of proteins and lipids in relation to different periods of fasting and refeeding were observed as constituting survival strategies used by $R$. quelen. Results showed that protein is an important source of energy during shorter fasting periods, whilst lipids are mobilized during longer ones. The metabolic activity of the liver as one of the principal tissues involved in satisfying energy needs during periods of restricted feeding was also evidenced by this study. In addition, there is strong evidence that the $R$. quelen species is extremely capable of replenishing energy reserves following different periods of fasting.

\section{Acknowledgements}

This work was supported by grants from FINEP 0106019000 (Financiadora de Estudos e Projetos), Unilasalle (Centro Universitário Lasalle) and Universidade de Passo Fundo (UPF).

\section{References}

ALBALAT, A., SÁNCHEZ-GURMACHES, J., GUTIÉRREZ, J. and NAVARRO, I., 2006. Regulation of lipoprotein lipase activity in rainbow trout (Oncorhynchus mykiss) tissues. General and Comparative Endocrinology, vol. 146, no. 3, pp. 226-235. PMid:16457827. http://dx.doi.org/10.1016/j.ygcen.2005.11.011.
Alliot, E., DJABAli, M., PAStoureaud, A. and THEBAULT, H., 1984. Changes in the biochemical composition of tissues in juvenile sea bass during forced starvation. Biochemistry and Systemathic Ecology, vol. 12, no. 2, pp. 209-213. http://dx.doi. org/10.1016/0305-1978(84)90038-3.

BARCELLOS, L.J.G., KREUTZ, L.C. and QUEVEDO, R.M., 2006. Previous chronic stress does not alter the cortisol response to an additional acute stressor in jundiá (Rhamdia quelen, Quoy and Gaimard) fingerlings. Aquaculture, vol. 253, no. 1-4, pp. 317-321. http://dx.doi.org/10.1016/j.aquaculture.2005.05.035.

BARCELLOS, L.J.G., KREUTZ, L.C., QUEVEDO, R.M., ROSA, J.G.S., KOAKOSKI, G., CENTENARO, L. and POTTKER, E., 2009. Influence of color background and shelter availability on jundiá (Rhamdia quelen) stress response. Aquaculture, vol. 288, no. 1-2, pp. 51-56. http://dx.doi.org/10.1016/j.aquaculture.2008.11.002.

BARCELLOS, L.J.G., MARQUEZE, A., TRAPP, M., QUEVEDO, R.M. and FERREIRA, D., 2010. The effects of fasting on cortisol, blood glucose and liver and muscle glycogen in adult jundiá Rhamdia quelen. Aquaculture, vol. 300, no. 1-4, pp. 231-236. http://dx.doi.org/10.1016/j.aquaculture.2010.01.013.

BARCELLOS, L.J.G., WOEHL, V.M., WASSERMANN, G.F., KRIEGER, M.H., QUEVEDO, R.M. and LULHIER, F., 2001. Plasma levels of cortisol and glucose in response to capture and tank transference in Rhamdia quelen (Quoy and Gaimard), a South American Catfish. Aquaculture Research, vol. 32, no. 2, pp. 123-125. http://dx.doi.org/10.1046/j.1365-2109.2001.00539.x.

BINES, J., 1999. Starvation and fasting. In: M.J. SADLER, J.J. STRAIN and B. CABALERRO, eds. Encyclopedia of human nutrition. New York: Academic Press. 2190 p. vol. 3.

BLACK, D. and LOVE, R.M., 1986. The sequential mobilization and restoration of energy reserves in tissues of Atlantic cod during starvation and refeeding. Journal of Comparative Physiology. B, Biochemical, Systemic, and Environmental Physiology, vol. 156, no. 4, pp. 469-479. http://dx.doi.org/10.1007/BF00691032.

BLASCO, J., FERNÁNDEZ, J. and GUTIÉRREZ, J., 1991. The effects of starvation and refeeding on plasma amino acid levels in carp, Cyprinus carpio L., 1758. Journal of Fish Biology, vol. 38, no. 4, pp. 587-598. http://dx.doi.org/10.1111/j.1095-8649.1991. tb03145.x.

BLASCO, J., FERNÁNDEZ, F. and GUTIÉRREZ, J., 1992. Fasting and refeeding in carp, Cyprinus carpio L.: the mobilization of reserves and plasma metabolite and hormone variations. Journal of Comparative Physiology B: Biochemical, Systemic, and Environmental Physiology, vol. 162, pp. 539-546. http:// dx.doi.org/10.1007/BF00264815.

BRADFORD, M.M., 1976. A rapid and sensitive method for the quantitation of microgram quantities of protein utilizing the principle of protein-dye binding. Analytical Biochemistry, vol. 72, no. 1-2, pp. 248-254. PMid:942051. http://dx.doi. org/10.1016/0003-2697(76)90527-3.

BRANDÃO-GONÇALVES, L. and SEBASTIEN, N.Y., 2013. Feeding activity and influence of intraspecific competition on zooplankton communities by jundiá (Rhamdia quelen Quoy and Gaimard, 1824) in laboratory. Brazilian Journal of Biology $=$ Revista Brasileira de Biologia, vol. 73, no. 4, pp. 765-773. PMid:24789392. http://dx.doi.org/10.1590/S1519-69842013000400012.

BUTLER, D.G., 1968. Hormonal control of gluconeogenesis in the North American eel (Anguilla rostrata). General and Comparative Endocrinology, vol. 10, no. 1, pp. 85-91. PMid:5646879. http:// dx.doi.org/10.1016/0016-6480(68)90012-9. 
CALOIN, M., 2004. Modeling of lipid and protein depletion during total starvation. American Journal of Physiology-Endocrinology, vol. 287, no. 4, pp. E790-E798. PMid:15165997. http://dx.doi. org/10.1152/ajpendo.00414.2003.

CAMARGO, A.C.S. and URBINATI, E.C., 2008. Influence of food restriction on the reproduction and larval performance of matrinxã, Brycon amazonicus (Spix and Agassiz, 1829). Brazilian Journal of Biology $=$ Revista Brasileira de Biologia, vol. 68, no. 4, pp. 869-873. PMid:19197507. http://dx.doi.org/10.1590/ S1519-69842008000400024

CZESNY, S., RINCHARD, J., GARCIA ABIADO, M.A. and DABROWSKI, K., 2003. The effect of fasting, prolonged swimming, and predator presence on energy utilization and stress in juvenile walleye (Stizostedion vitreum). Physiology \& Behavior, vol. 79, no. 4-5, pp. 597-603. PMid:12954400. http:// dx.doi.org/10.1016/S0031-9384(03)00124-0.

FARBRIDGE, K.J., FLETT, P.A. and LEATHERLAND, J.F., 1992. Temporal effects of restricted diet and compensatory increased dietary intake on thyroid function, plasma growth hormone levels and tissue lipid reserves of rainbow trout Oncorhynchus mykiss. Aquaculture, vol. 104, no. 1-2, pp. 157-174. http://dx.doi. org/10.1016/0044-8486(92)90146-C.

FIGUEIREDO-GARUTTI, M.L., NAVARRO, I., CAPILLA, E., SOUZA, R.H.S., MORAES, G., GUTIÉRREZ, J. and VICENTINI-PAULINO, M.L., 2002. Metabolic changes in Brycon cephalus (Teleostei, Characidae) during post-feeding and fasting. Comparative Biochemistry and Physiology A: Comparative Physiology, vol. 132, no. 2, pp. 467-476. PMid:12020663. http:// dx.doi.org/10.1016/S1095-6433(02)00094-6.

FOLCH, J., LEES, M. and SLOANE STANLEY, G.H., 1957. A simple method for the isolation and purification of total lipides from animal tissues. The Journal of Biological Chemistry, vol. 226, no. 1, pp. 497-509. PMid:13428781.

FUKUSHIMA, H., BAILONE, R.L., WEISS, L.A., MARTINS, M.L. and ZANIBONI-FILHO, E., 2012. Triploidy in the hematology of jundia juveniles (Siluriformes: Heptapteridae). Brazilian Journal of Biology $=$ Revista Brasileira de Biologia, vol. 72, no. 1, pp. 147-151. PMid:22437395. http://dx.doi.org/10.1590/ S1519-69842012000100017.

FURNÉ, M., MORALES, A.E., TRENZADO, C.E., GARCÍAGALLEGO, M., HIDALGO, M.C., DOMEZAIN, A. and SANZ, A., 2012. The metabolic effects prolonged starvation and refeeding in sturgeon and rainbow trout. Journal of Comparative Physiology, vol. 182B, no. 1, pp. 63-67. PMid:21698525. http:// dx.doi.org/10.1007/s00360-011-0596-9.

GOMES, L.C., GOLOMBIESKI, J., CHIPPARI-GOMES, A.R. and BALDISSEROTTO, B., 2000. Biologia do jundiá Rhamdia quelen (Teleostei, Pimelodidae). Ciência Rural, vol. 30, no. 1, pp. 179-185. http://dx.doi.org/10.1590/S0103-84782000000100029.

HEPHER, B., 1988. Nutrition of pond fishes. 1st ed. Cambridge: Cambridge University Press.

HERTRAMPF, J.W. and PIEDAD-PASCUAL, F., 2000. Handbook on ingredients for aquaculture feeds. Netherland: Kluwer Academic Publishers. $624 \mathrm{p}$

HERVANT, F., MATHIEU, J. and BARRE, H., 1999. Comparative study on the metabolic responses of subterranean and surfacedwelling amphipods to long-term starvation and subsequent refeeding. The Journal of Experimental Biology, vol. 202, no. 24, pp. 3587-3595. PMid:10574735.
INCE, B.W. and SO, S.T.C., 1984. Differential secretion of glucagon-like and somatostatin-like immunoreactivity from the perfused eel pancreas in response to d-glucose. General and Comparative Endocrinology, vol. 53, no. 3, pp. 389-397. PMid:6143708. http://dx.doi.org/10.1016/0016-6480(84)90267-3.

INUI, Y. and OSHIMA, Y., 1966. Effects of starvation metabolism and chemical composition of eels. Bulletin of the Japanese Society and Science and Fisheries, vol. 32, pp. 494-501.

JERÔNIMO, G.T., LAFFITTE, L.V., SPECK, G.M. and MARTINS, M.L., 2011. Seasonal influence on the hematological parameters in cultured Nile tilapia from southern Brazil. Brazilian Journal of Biology $=$ Revista Brasileira de Biologia, vol. 71, no. 3, pp. 719-725. PMid:21881796. http://dx.doi.org/10.1590/ S1519-69842011000400017.

KAMRA, S.K., 1966. Effect of starvation and refeeding on some liver and blood constituents of Atlantic cod (Gadus morhua L.). Journal of the Fisheries Research Board of Canada, vol. 23, no. 7, pp. 975-982. http://dx.doi.org/10.1139/f66-090.

KIM, J.H., JEONG, M.H., JUN, J.C. and KIM, T.I., 2014. Changes in hematological, biochemical and non-specific imune paramenters of Olive Flounder, Paralichtys olivaceus, following starvation. Asian Journal Animal Science, vol. 27, no. 9, pp. 13601367. PMid:25178381. http://dx.doi.org/10.5713/ajas.2014.14110.

KULLGREN, A., SAMUELSSON, L.M., LARSSON, D.G., BJORNSSON, B.T. and BERGMAN, E.J., 2010. A metabolomics approach to elucidate effects of food deprivation in juvenile rainbow trout (Oncorhynchus mykiss). American Journal of Physiology. Regulatory, Integrative and Comparative Physiology, vol. 299, no. 6, pp. 1440-1448. PMid:20861281. http://dx.doi.org/10.1152/ ajpregu.00281.2010

LARSSON, A. and LEWANDER, K., 1973. Metabolic effects of starvation in the eel, Anguilla anguilla L. Comparative Biochemistry and Physiology A: Comparative Physiology, vol. 44, no. 2, pp. 367-374. PMid:4145756. http://dx.doi.org/10.1016/03009629(73)90489-1.

LEWIS, T.L. and EPPLE, A., 1984. Effects of fasting, pancreatectomy, and hypophysectomy in the yellow eel, Anguilla rostrata. General and Comparative Endocrinology, vol. 55, no. 2, pp. 182-194. PMid:6479566. http://dx.doi.org/10.1016/00166480(84)90100-X

LOVE, R.M., 1980. The chemical biology of fishes. London: Academic Press. 943 p. vol. 2.

MACHADO, C.R., GAROFALO, M.A.R., ROSELINO, J.E.S., KETTELHUT, I.C. and MIGLIORINI, R.H., 1988. Effects of starvation, refeeding and insulin on energy-linked metabolic processes in catfish (Rhamdia hilarii) adapted to a carbohydraterich diet. General and Comparative Endocrinology, vol. 71, no. 3, pp. 429-437. PMid:3056774. http://dx.doi.org/10.1016/00166480(88)90272-9.

MACHADO, C.R., GAROFALO, M.A.R., ROSELINO, J.E.S., KETTELHUT, I.C. and MIGLIORINI, R.H., 1989. Effects of fasting on glucose turnover in a carnivorous fish Hoplias sp. The American Journal of Physiology, vol. 256, pp. 612-615.

MACKENZIE, D.S., VANPUTTE, C.M. and LEINER, K.A., 1998. Nutrient regulation of endocrine function in fish. Aquaculture, vol. 161 , no. $1-4$, pp. 3-25. http://dx.doi.org/10.1016/S00448486(97)00253-6.

MCCUE, M.D., 2010. Starvation physiology: reviewing the different strategies animals use to survive a common challenge. 
Comparative Biochemistry and Physiology A: Comparative Physiology, vol. 156, no. 1, pp. 1-18. PMid:20060056. http:// dx.doi.org/10.1016/j.cbpa.2010.01.002.

NARASIMHAN, P.V. and SUNDARARAJ, B.I., 1971. Effects of stress on carbohydrate metabolism in the teleost Notopterus notopterus (Pallas). Journal of Fish Biology, vol. 3, no. 4, pp. 441-447. http://dx.doi.org/10.1111/j.1095-8649.1971.tb05916.x.

NAVARRO, I., GUTIÉRREZ, J. and PLANAS, J., 1992. Changes in plasma glucagon, insulin and tissue metabolites associated with prolonged fasting in Brown trout (Salmo trutta fario). Comparative Biochemistry and Physiology. A: Comparative Physiology, vol. 102, no. 2, pp. 401-407. PMid:1354588. http:// dx.doi.org/10.1016/0300-9629(92)90154-I.

POWER, D.M., MELO, J. and SANTOS, C.R., 2000. The effect of food deprivation and refeeding on the liver, thyroid hormones and transthyretin in sea bream. Journal of Fish Biology, vol. 56, no. 2, pp. 374-387. http://dx.doi.org/10.1111/j.1095-8649.2000. tb02112.x

REINITZ, G., 1983. Relative effect of age, diet, and feeding rate on the body composition of young rainbow trout (Salmo gairdneri). Aquaculture, vol. 35, pp. 19-27. http://dx.doi.org/10.1016/00448486(83)90067-4.

ROSSI, A., CAZENAVE, J., BACCHETTA, C., CAMPANA, M. and PARMA, M.J., 2015. Physiological and metabolic adjustments of Hoplosternum littorale (Teleostei, Callichthyidae) during starvation. Ecological Indicators, vol. 56, pp. 161-170. http://dx.doi.org/10.1016/j.ecolind.2015.04.001.

SHERIDAN, M.A., 1988. Lipid dynamics in fish aspects of absorption, transportation, deposition, and mobilization. Comparative Biochemistry and Physiology B: Comparative Biochemistry, vol. 90, no. 4, pp. 679-690. PMid:3073911. http:// dx.doi.org/10.1016/0305-0491(88)90322-7.

SHERIDAN, M.A. and MOMMSEN, T.P., 1991. Effects of nutritional state on in vivo lipid and carbohydrate metabolism of coho salmon, Oncorhynchus kisutch. General and Comparative Endocrinology, vol. 81, no. 3, pp. 473-483. PMid:2055444. http:// dx.doi.org/10.1016/0016-6480(91)90175-6.
SHIMENO, S., KHEYYALI, D. and TAKEDA, M., 1990. Metabolic adaptation to prolonged starvation in carp. Nippon Sui Gak, vol. 56, no. 1, pp. 35-41. http://dx.doi.org/10.2331/ suisan.56.35.

SIGHOLT, T., ERIKSON, U., RUSTAD, T., JOHANSEN, S., NORDTVEDT, T.S. and SELAND, A., 1997. Handling stress and storage temperature affect meat quality of farmed-raised Atlantic salmon (Salmo salar). Journal of Food Science, vol. 62, no. 4, pp. 898-905. http://dx.doi.org/10.1111/j.1365-2621.1997.tb15482.x.

SOUZA, V.L., OLIVEIRA, E.G. and URBINATI, E.C., 2000. Effects of food restriction and refeeding on energy stores and growth of pacu, Piaractus mesopotamicus (Characidae). Journal of Aquaculture in the Tropics, vol. 15, pp. 371-379.

SOUZA, V.L., URBINATI, E.C., MARTINS, M.I.E.G. and SILVA, P.C., 2003. Avaliação do crescimento e do custo da alimentação do pacu (Piaractus mesopotamicus Holmberg, 1887) submetido a ciclos alternados de restrição alimentar e realimentação. Revista Brasileira de Zootecnia, vol. 32, no. 1, pp. 19-28. http://dx.doi. org/10.1590/S1516-35982003000100003.

STIRLING, H.P., 1976. Effects of experimental feeding and starvation on the proximate composition of the European bass Dicentrarchus labrax. Marine Biology, vol. 34, no. 1, pp. 85-91. http://dx.doi.org/10.1007/BF00390791.

THOMAS, P.M., PANKHURST, N.W. and BREMNER, H.A., 1999. The effect of stress and exercise on post-mortem biochemistry of Atlantic salmon and rainbow trout. Journal of Fish Biology, vol. 54, no. 6, pp. 1177-1196. http://dx.doi. org/10.1111/j.1095-8649.1999.tb02047.x.

VAN DEN THILLART, G. and VAN RAAIJ, M., 1995. Endogenous fuels; non-invasive versus invasive approaches. In: P.W. HOCHACHKA and T.P. MOMMSEN, eds. Biochemistry and molecular biology of fishes. New York: Elsevier, pp. 33-36. Metabolic Biochemistry, vol. 43.

WEATHERLEY, A.H. and GILL, H.S., 1987. The biology of fish growth. London: Academic Press. 443 p. 